\title{
HYPOXIC GAS MIXTURES DELIVERED BY ANAESTHETIC MACHINES EQUIPPED WITH A DOWNSTREAM OXYGEN FLOWMETER
}

\author{
D.C. Chung, Q-C Jing, L. Prins and J. Strupat
}

\begin{abstract}
The oxygen cancentration of fresh gas mixtures delivered to a Bain circuit by a Boyle's anaesthetic machine equipped with leaking oxygen flowmeters was measured at the common gas outlet during free flow and during controlled ventilation of a model lung. The results demonstrate that, despite satisfactory oxygen and nitrous oxide rotameter settings, such a machine can deliver hypoxic fresh gas mixtures irrespective of whether the leaking flowmeter is mounted downstream or upstream. This selective loss of oxygen increases with the size of the leak and increases with the back pressure on the flowmeter assembly during controlled ventilation. A downstream position of the oxygen flowmetre should not be regarded as foolproof. Continuous monitoring of the oxygen concentration of fresh gas mixtures with an in-line oxygen analyzer is recommended.
\end{abstract}

EGER, et al.' WERE THE FIRST to point out that anaesthetic machines equipped with an upstream oxygen flowmeter could deliver a hypoxic mixture, despite deceptively satisfactory flowmeter readings, should there be a leak in the oxygen or other flowmeters. They suggested that this danger could be reduced if the oxygen flowmeter was mounted in a downstream position immediately proximal to the outlet of the common collecting chamber. Since then, fatal and nearfatal accidents due to hypoxic fresh gas mixtures delivered by anaesthetic machines equipped with an upstream oxygen flowmeter have been reported. ${ }^{2-5}$ In 1978 the Canadian Standards Association adopted Eger's recommendation ${ }^{6}$ which was endorsed by the Canadian Anaesthetists' Society? and later implemented by anaesthetic departments across the country.

Many newer anaesthetic machines are equipped with only nitrous oxide and oxygen flowmeters. There is an equal chance for a leak to occur in either flowmeter in such a machine. When the leak is in the upstream nitrous oxide flowmeter, selective loss of oxygen will not occur." Should the leak occur in the downstream

D.C. Chung, M.D., F.R.C.P.(C), Assistant Professor, Department of Anaesthesia, University Hospital, University of Western Ontario, London, Ontario, Canada.

Q-C Jing, Senior Anaesthetist, Peking Tuberculosis Research Institute, Peking, China.

L. Prins, R.R.T., and J. Strupat, R.R.T., Respiratory Technologists, Department of Respiratory Technology, University Hospital, London, Ontario, Canada.

Address reprint requests to Dr. D.C. Chung. Department of Anaesthesia, University Hospital, 339 Windermere Road, London, Ontario, Canada. N6A 5A5. 527 oxygen flowmeter, the delivery of a hypoxic mixture cannot be ruled out - a possibility not explored in previous studies. The following investigation was designed to look into the effect of such a leak on the oxygen concentration of the fresh gas mixture delivered by such a machine and to determine the effect of back pressure during controlled ventilation on such a leak.

\section{Methods}

The anaesthetic machine examined was a standard Boyle's machine (British Oxygen Company M-222) equipped with a back-flow check valve on the back bar and fitted with a Bain circuit. Other equipment used in the study included a mass spectrometer (Perkin-Elmer Medical Gas Analyzer 1100) for the analysis of the oxygen concentration of the fresh gas mixture, a model lung (a one-litre reservoir bag filled with a sponge and restricted by a $2.5 \mathrm{~cm}$ rubber waist band) and a ventilator (Penlon Series 200).

The investigation was done in two parts:

(I) In Part I, the oxygen flowmeter was mounted downstream and leaks in the machine were ruled out with the help of Snoop ${ }^{\circledR}$ (a leakdetecting solution). With the oxygen and nitrous oxide rotameters set at two and four litres per minute respectively, the oxygen concentration of the fresh gas mixture at the common gas outlet of the anaesthetic machine (the outlet port from which fresh gas mixture is delivered to the Bain circuit) was measured continuously when:

(a) there was no leak in the system and the fresh gas mixture was allowed to flow through the Bain circuit venting freely into the atmosphere.

Canad. Anaesth. Soc. J., vol. 27, no. 6, November 1980 


\section{TABLE I}

The Effect of Leaks in a Downstream Oxygen Flowmeter on the Oxygen Concentration of Fresh Gas MLxtures

\begin{tabular}{|c|c|c|c|c|c|c|c|}
\hline \multirow{3}{*}{$\begin{array}{c}\begin{array}{c}\text { Fresh } \\
\text { gas flows }\end{array} \\
\mathrm{O}_{2}: \mathrm{N}_{2} \mathrm{O} \\
\mathrm{l} / \mathrm{min}\end{array}$} & \multicolumn{7}{|c|}{ Oxygen concentration of fresh gas mixtures (per cent) } \\
\hline & \multicolumn{3}{|c|}{ Free flow } & \multicolumn{2}{|c|}{$\begin{array}{c}1.5 \mathrm{kPa}(15 \mathrm{~cm} \\
\left.\mathrm{H}_{2} \mathrm{O}\right)\end{array}$} & \multicolumn{2}{|c|}{$\begin{array}{c}3 \mathrm{kPa}(30 \mathrm{~cm} \\
\left.\mathrm{H}_{2} \mathrm{O}\right)\end{array}$} \\
\hline & No leak & 1 hole & 2 holes & 1 hole & 2 holes & 1 hole & 2 holes \\
\hline $2: 4$ & 34 & 29 & 24 & 24 & $18^{*}$ & 21 & $15^{*}$ \\
\hline $2: 5$ & 30 & 25 & 21 & 22 & $16^{*}$ & $17^{*}$ & $12^{*}$ \\
\hline $2: 8$ & 21 & $15^{*}$ & $12^{*}$ & $12^{*}$ & $8^{*}$ & $9^{*}$ & $5^{*}$ \\
\hline $3: 6$ & 33 & 29 & 25 & 25 & $19^{*}$ & 22 & $16^{*}$ \\
\hline
\end{tabular}

*Indicates hypoxic gas mixture.

TABLE II

The Effect of Leaks in an Upstream Oxygen Flowmeter on the Oxygen Concentration of Fresh Gas Mixtures

\begin{tabular}{|c|c|c|c|c|c|c|c|}
\hline \multirow{3}{*}{$\begin{array}{c}\begin{array}{c}\text { Fresh } \\
\text { gas flows }\end{array} \\
\mathrm{O}_{2}: \mathrm{N}_{2} \mathrm{O} \\
\mathrm{l} / \mathrm{min}\end{array}$} & \multicolumn{7}{|c|}{ Oxygen concentration of fresh gas mixtures (per cent) } \\
\hline & \multicolumn{3}{|c|}{ Free flow } & \multicolumn{2}{|c|}{$\begin{array}{c}1.5 \mathrm{kPa}(15 \mathrm{~cm} \\
\left.\mathrm{H}_{2} \mathrm{O}\right)\end{array}$} & \multicolumn{2}{|c|}{$\begin{array}{c}3 \mathrm{kPa}(30 \mathrm{~cm} \\
\left.\mathrm{H}_{2} \mathrm{O}\right)\end{array}$} \\
\hline & No leak & 1 hole & 2 holes & 1 hole & 2 holes & 1 hole & 2 holes \\
\hline $2: 4$ & 33 & 26 & 20 & $18^{*}$ & $8 *$ & $10^{*}$ & $4^{*}$ \\
\hline $2: 5$ & 28 & 21 & $14^{*}$ & $13^{*}$ & $4^{*}$ & $6^{*}$ & $2^{*}$ \\
\hline $2: 8$ & 20 & $12^{*}$ & $4^{*}$ & $6^{*}$ & $1^{*}$ & $2^{*}$ & $0^{*}$ \\
\hline $3: 6$ & 32 & 25 & $19 *$ & $18^{*}$ & $8^{*}$ & $10^{*}$ & $3^{*}$ \\
\hline
\end{tabular}

*Indicates hypoxic gas mixture.

(b) a leak was created in the upper end of the oxygen flowmeter by the insertion of a 16-gauge needle through the rubber mount at the upper end of the oxygen flowmeter and the fresh gas mixture was allowed to flow through the Bain circuit venting freely into the atmosphere.

(c) the leak was increased by the insertion of a second 16-gauge needle through the rubber mount and the fresh gas mixture was allowed to flow through the Bain circuit venting freely into the atmosphere.

(d) leaks were present as in (b) and (c) but the fresh gas mixtures were used to ventilate the model lung with the Bain circuit to peak inflation pressures of 1.5 and $3 \mathrm{kPa}$ ( 15 and $30 \mathrm{~cm}$ water) with the ventilator.

These measurements were then repeated with oxygen and nitrous oxide flows set at two and five, at two and eight and at three and six litres per minute.

(II) In part II, the oxygen flowmeter was rearranged to occupy the upstream position and leaks were again ruled out. With smilar oxygen and nitrous oxide flows, the oxygen concentration of each combination of fresh gas was again measured under conditions outlined in (a) to (d).

\section{Results}

These leaks in the oxygen flowmeter did not affect the rotameter settings of the oxygen or nitrous oxide flowmeters. Their effect on the oxygen concentration of fresh gas mixtures is recorded in Tables I and II. During free flow, the oxygen concentration of the fresh gas mixture was constant. During controlled ventilation, the oxygen concentration varied with the phasic changes in pressure - it was lowest when inflation pressure was at its peak, it was highest at the end of expiration and equalled that during free flow with the respective leak. The tabulated results are the lowest concentration observed at the peak of inflation.

(I) When the intact oxygen flowmeter was mounted downstream (Table I), the oxygen concentration of the gas mixtures delivered was an 
accurate reflection of the oxygen fraction of the set fresh gas flows. When a leak was present in the oxygen flowmeter, there was a fall in the oxygen concentration of the gas mixtures delivered at all fresh gas flows. This fell further when the leak was increased. It fell even more when ventilation was controlled and the extent of this fall increased in steps as peak inflation pressure was increased from $1.5 \mathrm{kPa}$ to $3 \mathrm{kPa}(15 \mathrm{~cm}$ to $30 \mathrm{~cm}$ water). At the higher peak inflation pressure and with the larger leak, the gas mixtures delivered were uniformly hypoxic at all set fresh gas flows.

(II) When the intact oxygen flowmeter was mounted upstream (Table II), the oxygen concentration of the gas mixtures delivered was again an accurate reflection of the oxygen fraction of the set fresh gas flows. In the presence of a leak, oxygen concentration of the delivered gas mixtures fell. The extent of this fall increased when the size of the leak was increased and when controlled ventilation was introduced. Comparing data from Tables I and II, it can be seen that the fall in oxygen concentration was more serious when the leaking oxygen flowmeter was upstream than when it was downstream. At the higher peak inflation pressure and with the larger leak, the gas mixtures delivered were almost anoxic at all set fresh gas flows when the oxygen flowmeter was mounted upstream.

\section{Discussion}

The oxygen concentration of fresh gas mixtures delivered by a Boyle's anaesthetic machine equipped with leaking oxygen flowmeters was measured. Our results confirm Eger's' finding that an anaesthetic machine equipped with an upstream oxygen flowmeter can deliver a hypoxic mixture to the patient, should there be a leak in this flowmeter. They also demonstrate that this danger is not entirely eliminated by mounting the oxygen flowmeter downstream. An anaesthetic machine equipped with a downstream oxygen flowmeter can still deliver a hypoxic gas mixture if this flowmeter has a leak. These leaks have no observable effects on the position of the rotameter float. Although this loss of oxygen is more serious when the oxygen flowmeter is upstream, this selective loss is still highly dangerous when the flowmeter is downstream.

The loss of oxygen increases with the size of the leak. The leaks created in this study are not large enough to be detected by the usual method of allowing pressure to build up passively in the
Bain circuit and the reservoir bag until the Norry valve blows off at $5.3 \mathrm{kPa}(40 \mathrm{~mm} \mathrm{Hg})$. Yet the drop in oxygen concentration is alarming at all fresh gas flows. With larger leaks, the danger of delivering a hypoxic mixture will no doubt be more serious.

Despite the presence of the back-flow check valve, this selective oxygen loss also increases with the peak inflation pressure when respiration is controlled because, although this valve prevents the direct transmission of back pressure from the ventilator to the flowmeter assembly, the continuous inflow of oxygen and nitrous oxide will cause a build-up of pressure proximal to the check valve, which is transmitted to the flowmeters. To maintain adequate ventilation, patients with increased pulmonary impedance (e.g. the bronchitic and the obese) may need a high inflation pressure during controlled ventilation. Under these circumstances the oxygen leak is particularly serious. Therefore the chance of delivering a hypoxic mixture to patients who are more susceptible is increased.

Minor leaks in anaesthetic machines that cannot be detected by simply pressurizing the circuit are common. Although a specific leak at the oxygen flowmeter must be relatively rare, leaks in other areas can also have a less predictable effect on the loss of oxygen and lead to the delivery of a hypoxic mixture. It must be emphasized that the oxygen failure protection device recommended by the Canadian Standards Association ${ }^{6}$ and installed in all anaesthetic machines only gives warning of failure of the oxygen supply from the pipeline or the tank. Loss of oxygen through the flowmeter assembly or distal to it will not activate this alarm. The anaesthetized patient is illequipped to cope with hypoxaemia because of impaired ventilatory ${ }^{8-10}$ and circulatory ${ }^{11}$ responses. This study lends support to the continuous monitoring of the oxygen concentration of the fresh gas mixture with an in-line oxygen analyzer, which is strongly recommended in a more current publication of the Canadian Standards Association. ${ }^{12}$

The Canadian Standards Association must be given credit for establishing a uniform downstream position for the oxygen flowmeter of anaesthetic machines across the country. However, this position must not be regarded as foolproof. A constant awareness on the part of the anaesthetist that his equipment can fail and his readiness to meet such an emergency at all times are still required in the safe practice of anaesthesia. 


\section{ACKNOWLEDGEMENTS}

The authors wish to thank their colleagues for valuable suggestions and are grateful to $\mathrm{J}$. Roberts and L. Nolan for their assistance in the preparation of the manuscript.

\section{REFERENCES}

I. Eger, E.I., Hylton, R.R., Irwin, R.H. \& GUADAGNI, N. Anesthetic flow meter sequence - a cause for hypoxia. Anesthesiology 24: 396 (1963).

2. Bishop, C., Levick, C.H. \& Hodgson, C. A design fault in the Boyle apparatus. Brit. J. Anaesth. 39: 908 (1967).

3. KATZ, D. Recurring cyanosis of intermittent mechanical origin in anesthetized patients. Anesth. Analg. 47: 233 (1968).

4. Liew, P.C. \& GANEndran, A. Oxygen failure: a potential danger with air-flowmeters in anaesthetic machine with remote controlled needle valves. Brit. J. Anaesth. 45: 1165 (1973).

5. GuPTA, B.L. \& VARShNeYA, A.K. Anaesthetic accident caused by unusual leakage of rotameter. Brit. J. Anaesth. 47: 805 (1975).
6. Continuous flow inhalation anaesthetic apparatus (anaesthetic machines) for medical use, CSA Preliminary Standard Z168.3-M1978. Canadian Standards Association, Rexdale, Ontario ( 1978).

7. Guidelines for the Minimal Standards of Practice of Anaesthesia. The Canadian Anaesthetists' Society Incorporated, Toronto, Ontario (1977).

8. KNill, R.L., Bright, S. \& Manninen, P. Hypoxic ventilatory responses during thiopentone sedation and anaesthesia in man. Canad. Anaesth. Soc. J. 25: 366 (1978).

9. KNILL, R.L. \& GELB, A.W. Ventilatory responses to hypoxia and hypercapnia during halothane sedation and anesthesia in man. Anesthesiology 49: 244 (1978).

10. KNill, R.L., ManNinen, P.H. \& Clement, J.L. Ventilation and chemoreflexes during enflurane sedation and anaesthesia in man. Canad. Anaesth. Soc. J. 26: 353 (1979).

11. Manninen, P. \& KNill, R.L. Cardiovascular signs of acute hypoxaemia and hypercarbia during enflurane and halothane anaesthesia in man. Canad. Anaesth. Soc. J. 26: 282 (1979).

12. Continuous-flow inhalation anaesthetic apparatus (anaesthetic machine) for medical use, CSA Standard ZI68.3-M 1980. Canadian Standards Association, Rexdale, Ontario (1980).

\section{RÉSUMÉ}

La concentration en oxygène du mélange de gaz frais fourni au circuit Bain par le débitmètre d'oxygène d'un appareil Boyle sur lequel on avait créé une fuite a été mesurée à l'orifice d'émission lors de l'écoulement libre et lors de la ventilation contrôlée. Les résultats ont démontré que malgré un réglage satisfaisant des rotamètres de l'oxygène et du protoxyde d'azote, on pouvait obtenir de l'appareil des mélanges hypoxiques indépendemment du montage en amont ou en aval du débitmètre. Cette perte sélective de l'oxygène s'accroît avec l'importance de la fuite ainsi qu'avec la contre-pression imposée au débitmètre par la ventilation contrôlée. Le fait d'installer un débitmètre d'oxygène en aval ne protège donc pas de ce danger. Un monitorage continu de la concentration en oxygène des mélanges gazeux avec un analyseur est recommandé. 